\title{
LINGUOCULTURAL COMPETENCE AS A BASIS FOR FOREIGN LANGUAGE PROFICIENCY
}

\author{
COMPETÊNCIA LINGUOCULTURAL COMO BASE PARA PROFICIÊNCIA EM LÍNGUA \\ ESTRANGEIRA
}

\section{LA COMPETENCIA LINGUOCULTURAL COMO BASE DEL DOMINIO DE LA LENGUA EXTRANJERA}

\author{
Elena Antonovna TULUSINA ${ }^{1}$ \\ Aida Gumerovna SADYKOVA ${ }^{2}$ \\ Zarema Mukhtarovna ZARIPOVA ${ }^{3}$ \\ Charles Frederic CARLSON ${ }^{4}$
}

\begin{abstract}
The article is devoted to the problem of formation of linguistic and cultural competence during foreign language classes in the middle school. The influence of intercultural interference will be significantly offset by the inclusion of linguoculturological aspects in the content of teaching foreign language, which could serve as a system of unifying values that allow us to understand the boundaries of our own linguistic identity and the identity of a native speaker's language. The article analyzes the results of a pedagogical experiment aimed at the formation of linguoculturological competences of students in middle school. All teaching methods and techniques were oriented to stimulate the students' creative speech activity, as well as cognitive aspects, which increased the efficiency of teaching the foreign language. The authors confirmed the hypothesis that the process of teaching foreign language will be more successful if the linguoculturological aspect is included in the content of what is taught, comprising the use of linguistic and cultural information as a valuable source of linguocultural material. For that reason, the conditions for successful assimilation of knowledge, the formation and improvement of linguocultural competence in the foreign language lesson in the middle school were created. The results of a pedagogical experiment could be used in a foreign language lesson in middle school.
\end{abstract}

KEYWORDS: Linguoculturology. Intercultural interference. Linguistic identity. German. Russian.

RESUMO: O artigo se dedica ao problema da formação da competência linguística e cultural durante uma aula de língua estrangeira no Ensino Fundamental II. A influência da interferência intercultural será significativamente compensada pela inclusão do aspecto

${ }^{1}$ Kazan Federal University (KPFU), Kazan - Russia. Associate Professor of the Department of General Linguistics and Turkology, Institute of Philology and Intercultural Communication. PhD in Philology. ORCID: https://orcid.org/0000-0001-6691-4225. E-mail: elena tulusina@mail.ru

${ }^{2}$ Kazan Federal University (KPFU), Kazan - Russia. Professor of the Department of General Linguistics and Turkology, Institute of Philology and Intercultural Communication, $\mathrm{PhD}$ in Philology. ORCID: https://orcid.org/0000-0001-5358-4087.E-mail: aida.sadykova@ksu.ru

${ }^{3}$ Kazan Federal University (KPFU), Kazan - Russia. Associate Professor of the Department of General Linguistics and Turkology, Institute of Philology and Intercultural Communication, $\mathrm{PhD}$ in Philology. ORCID: https://orcid.org/0000-0003-2232-1895.E-mail: zaripovaz@mail.ru

${ }^{4}$ Kyrgyz-Turkish Manas University (KTMÜ), Bishkek - Kyrgyzstan. Professor. ORCID: https://orcid.org/00000003-2896-5122. E-mail: carlson@manas.kg 
linguoculturológico no conteúdo do ensino de língua estrangeira, o que poderia servir como um sistema de valores unificadores que nos permite compreender os limites de nossa própria identidade linguística e a identidade de um nativo falante da língua. $O$ artigo analisa os resultados de uma experiência pedagógica voltada para a formação da competência linguoculturológica de alunos do ensino médio. Todos os métodos e técnicas de ensino foram orientados para estimular a atividade de fala criativa dos alunos, bem como cognitiva, o que aumentou a eficiência do ensino da língua estrangeira. Os autores confirmaram a hipótese de que o processo de ensino de língua estrangeira terá mais sucesso se o aspecto linguoculturológico estiver incluído no conteúdo desse ensino, compreendendo a utilização de informações linguísticas e culturais como fonte valiosa de material linguocultural. Por isso, foram criadas as condições para uma assimilação bem-sucedida de conhecimentos, a formação e o aprimoramento da competência linguocultural na aula de língua estrangeira. Os resultados de uma experiência pedagógica podem ser usados em uma aula de língua estrangeira no Ensino Fundamental II.

PALAVRAS-CHAVE: Linguoculturologia. Interferência intercultural. Identidade linguística. Alemão. Russo.

RESUMEN: El artículo está dedicado al problema de la formación de competencias lingüisticas y culturales durante una lección de lengua extranjera en una escuela secundaria. La influencia de la interferencia intercultural se verá compensada significativamente por la inclusión del aspecto lingüistico-cultural en el contenido de la enseñanza de la lengua extranjera, que podría servir como un sistema de valores unificadores que nos permitan comprender los límites de nuestra propia identidad lingüistica y la identidad de un nativo. el idioma del hablante. El artículo analiza los resultados de un experimento pedagógico dirigido a la formación de la competencia lingüistica cultural de los estudiantes de la escuela media. Todos los métodos y técnicas de enseñanza fueron orientados a estimular la actividad del habla creativa de los estudiantes, así como la cognitiva, lo que aumentó la eficiencia de la enseñanza de la lengua extranjera.Los autores confirmaron la hipótesis de que el proceso de enseñanza de la lengua extranjera será más exitoso si se El aspecto lingüistico se incluye en el contenido de esa enseñanza, que comprende el uso de información lingüistica y cultural como una fuente valiosa de material lingüístico cultural. Por esa razón, se crearon las condiciones para la asimilación exitosa de conocimientos, la formación y mejora de la competencia lingüística en la lección de lengua extranjera en la escuela media. Los resultados de un experimento pedagógico podrían usarse en una lección de lengua extranjera en la escuela secundaria.

PALABRAS CLAVE: Lingüoculturología. Interferencia intercultural. Identidad linguística. Alemán. Ruso.

\section{Introduction}

The topicality of this research is due to the rapid development of cultural and economic relations between different countries and active globalization processes. In this regard, there is a growing role for the study of foreign languages, and a demand for specialists mastering foreign languages. 
Nevertheless, there is an insufficient level of knowledge on foreign languages by graduates of schools and language universities, as well as an insufficient level of formation of competencies that contribute to the effective use of foreign language in the domestic sphere and professional communication, including linguocultural competence. An important role in that case is also played by information of a linguoculturological nature, information about another language, traditions and modern developmental features of representatives of other ethnocultural societies. The cultural component of the environment is no less important than its linguistic component (MUKHAMADIAROVA ALBINA; MERKISH NATALIYA; KULKOVA MARIYA, 2018).

Under linguoculturological competence we understand the system of linguistic and cultural knowledge, skills and abilities mastered by students in the lessons of foreign language.

\section{Methods}

In the course of the attainment of the objectives the following research methods were used: a descriptive method, observation, an experimental method, a method of linguoculturological analysis of language material, a method of continuous sampling, an elementary statistical method and a method of a graphical display of research results.

In order to demonstrate the positive dynamics of the formation of linguoculturological competence of students while studying the foreign language, an experiment was conducted. It was carried out in 3 stages:

1. Ascertaining stage. Primary assessment of the level of formation of linguoculturological competence;

2. Formative stage. A lesson in the form of game aimed at the formation of linguistic and cultural competence while studying a foreign language by representation of stereotypical statements about a native speaker;

3. The final stage. Reassessment of the level of formation of linguoculturological competence while studying a foreign language.

The main tools in the process of formation of linguoculturological competence were authentic materials and educational speech situations that allowed us to improve students' knowledge about the culture of the nation. Thus, the students got acquainted with new linguistic phenomena and analyzed the features of their use in speech. 
The tasks proposed to the participants of the pedagogical experiment were both theoretical and practical and examined:

- knowledge of the functional and semantic features of proverbs and sayings in a foreign language, the formation of an idea of their role in speech;

- the ability to analyze the functioning of proverbs and sayings in speech situations;

- the ability to use the words and expressions with national specificity in accordance with the conditions of the speech situation;

- the ability to create your own statement using proverbs and sayings;

- the ability to adequately respond to the situations containing a linguoculturalogical component;

- the ability to complete the educational speech situation and academic dialogue using the statements adopted in the linguistic culture of the studied language.

In the process of the pedagogical experiment the following methods were used: explanatory and illustrative, partially-search, method of problematic introduction of material, communicative approach (educational games, conversation on a given topic).Teaching methods are implemented by the teacher through the techniques that are used in a form of special activity that students need to accomplish with the new language material: presentation of new language material either orally or in written form, in the form of a single expression or in the context, using illustrative material, etc.

\section{Results and discussion}

As part of our study, we analyzed the principles and criteria for selecting linguocultural markers and applied the obtained results to the foreign language lessons in the middle school.

Thus, we came to the conclusion, that in order to successfully master linguocultural components, it is important for students to be guided by the selection principles identified by Zhumasheva: thematic-situational principle, the principle of communicativeness, the principle of informational value of paremia, the principle of frequency, the principle of system functional approach, the principle of methodological expediency, the principle of considering the students' mother tongue. Levels of a linguocultural interference in the conditions of dialogue of cultures are established. Components of a linguocultural interference in the conditions of dialogue of cultures are allocated and their reasons are established (ZHUMASHEVA et al., 2014). 
In the process of formation of students' linguoculturological competence such methods as comparison, juxtaposition, substitution, creation of monologues and situations on a given topic were used. Teaching methods and techniques form the basis of exercises, because they allow to manage students' learning activity, their involvement and interest, because:

the secondary language personality is viewed by modern linguistics as abilities to communicate in foreign languages. It is difficult to overestimate the importance of that conclusion for the process of teaching a foreign language as it assumes basic distinctions in the choice of teaching methods for various groups of language learners (ZHUMASHEVA et al., 2014).

In accordance with the topics of the training and methodology complex named «Горизонты»for the 6th grade, the pedagogical experiment was carried out in 3 stages, each of which was associated with the accumulation of formed skills:

1) recognition of a nationalspecific situation with the help of illustrative material and contextual guessing and an ability to explain the content of occurrence;

2) secondary consolidation of linguistic material with a linguoculturological component through educational games and exercises;

3) independent creative activity through speech exercises.

In an ascertaining assignment, situations with a linguoculturological component were used, and the meanings of that components students could identify from the context by using previously studied lexemes. To identify the level of linguoculturological competence formation, students were offered assignments to compare the stereotypic statements in their mother tongue and foreign language; the search for equivalents for the transmission of foreign language proverbs and sayings; filling in the gaps. The cognitive research of proverbs was carried out through: grouping and interpreting of proverbs and sayings with a particular feature and rubrics in dictionaries of proverbs and sayings.

The results of the assignment are shown in the following diagram, where we revealed the level of formation of linguoculturological competence of students:

Scholars in cultural linguistics and psycholinguists assign a special role to association experiment as one of the most important research methods (TULUSINA; SADYKOVA; FREDERIC, 2017). During the experiment, the efficiency of the process of formation of linguistic and cultural competence of students was examined in accordance with the concept of phased formation and development of a linguistic person. The main goal of the experiment is to check the effectiveness of the developed methodology for the formation of 
linguoculturological competence: 1) to establish the level of formation of linguoculturological competence while study in the linguistic units with a linguistic and cultural aspect (proverbs and sayings);2) to verify the optimality of the combination of methods and techniques aimed at the formation of linguocultural competence; 3) determine the effectiveness of the use of strategies for mastering educational material in the proposed set of exercises.

Diagram 1 - The level of formation of linguoculturological competence of students at the control stage.

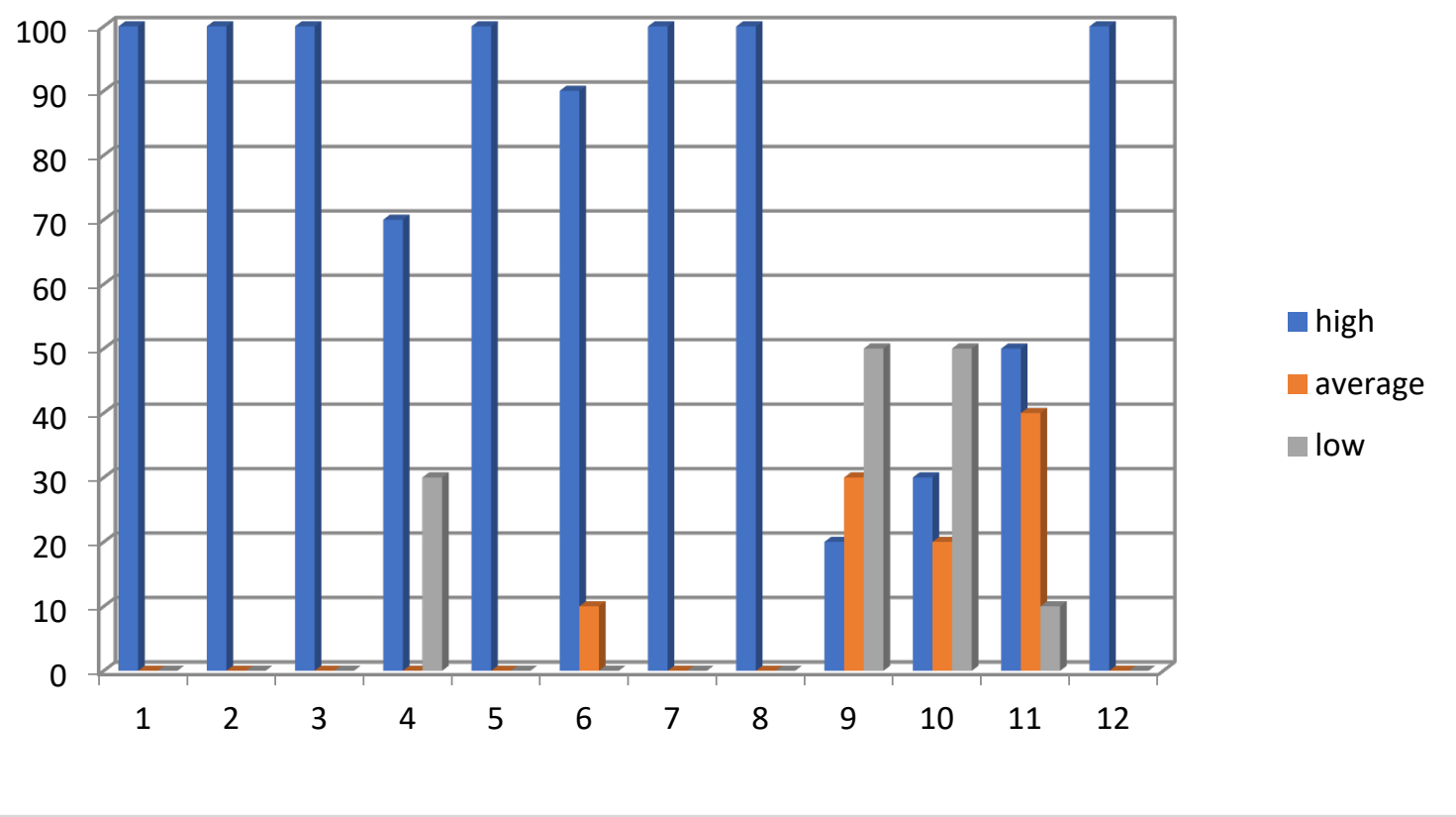

Source: Developed by the authors

As a preparatory exercise for motivation to educational and cognitive activities, students were asked to divide into 2 teams and recall the largest number of proverbs and sayings of the Russian language. New language material was presented along with illustrative one, as a result of which students successfully identified the meaning of the given stable expressions. To improve the skill of contextual guessing, students were asked to find Russian equivalents for the corresponding pairs of foreign language. The described exercises are aimed at memorizing proverbs and sayings, since they require the ability to analyze the given units and use proverbs and sayings in speech, understand and use cultural information in the process of communication. In the process of their implementation, students were forced to turn to the dictionary several times and clarify the meaning of the given language units. The discrepancy between the meanings of the proverbs in mother tongue and foreign language or the lack of the equivalent of the given proverb in the Russian language arouses the interest of the students and 
promotes the activity during the lesson. Then the students were able to consolidate the proverbs and sayings in a game format: a) through pantomime; b) through a creative task. The results of the final stage are reflected below (see Diagram 2), where «high», «average», «low» reflects the level of development of the studied material at the formative stage:

Diagram 2 - The results of the ascertaining and control test for the formation of the level of linguoculturological competence

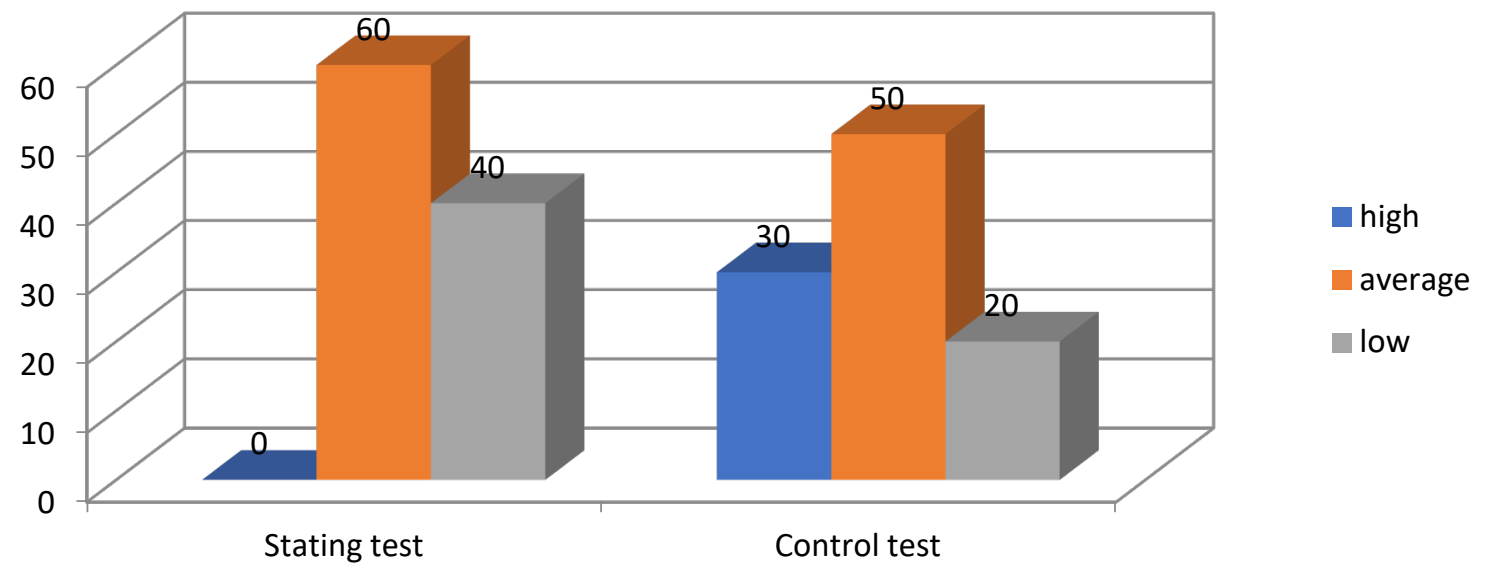

Source: Developed by the authors

When comparing the results of the ascertaining and control test, it is clear that the number of students who successfully completed the tasks increased from $60 \%$ to $80 \%$, which is evidence of the efficiency of the system of exercises aimed at the development of linguoculturological competence. It was also noticed that students had certain difficulties with writing proverbs and sayings, which indicates that it is necessary to include exercises aimed at memorizing the written form of proverbs and sayings in order to avoid mistakes in written speech.

As the analysis showed, despite the existing system of communicative and grammatically directed exercises for vocabulary, paremiological material is not represented enough in this system, in spite of the fact, that linguistic and regional material is provided by the authors of the textbook. Since the textbook provides a large amount of information for teaching a foreign language, there is the lack of attention for proverbs and sayings due to the time limit.

Further a description of the pedagogical experiment, which consisted of ascertaining, formative and control stages is provided. 
At the first stage we examined the level of formation of linguocultural competence of students in the form of a test. The main task was to determine the meaning of proverbs and sayings of a foreign language, with which $60 \%$ of students successfully coped.

The formative stage consisted of a lesson in the form of game. At this stage studentsgot acquainted with new language material. The results of the exercises presented a positive dynamic of the formation of linguoculturological competence of students.

The results of the control stage, carried out after the formative one, showed that the level of formation of linguoculturological competence of students has become higher. This became an important incentive for developing contextual guessing, imagination and improving phonemic awareness.

Approbation of the principles, methods, and techniques of formation of linguoculturological competence of students while studying foreign language paramideas, proves that their combination provides a higher level of formation of linguoculturological knowledge and skills. Most phraseological units are built according to some semantic template and the possibility of distinguishing one or more key components within them is assumed (AYUPOVA et al., 2020).

The experiment has proved the effectiveness of the methodology of formation oflinguocultural competence. All teaching methods and techniques were focused on stimulating students' creative speech and cognitive activity, which increased the efficiency of teaching the German language, forming conditions for a solid assimilation of knowledge and the formation and improvement of linguocultural competence. The effectiveness of the learning process is possible due to the methods and techniques of presenting linguistic material and the features of its perception and assimilation by students. Teachers could do to form their own individual professional educational route within lifelong professional educational environment.

\section{Summary}

Foreign language teaching contributes to the formation and upbringing of a comprehensively developed personality, which is one of the most important objectives of our time. The main goal of teaching foreign language in middle school is the formation of communicative competence, an important component of which is linguoculturological competence. In this study, we define linguocultural competence as the willingness and ability of students interact in an intercultural dialogue and also "reflect cultural and social characteristics" (GURYANOV; RAKHIMOVA; RUDNICK, 2017). Therefore, the main 
objective of a modern teacher of a foreign language is to include each child in the learning process by creating special situations that enhance the motivation and students' creative activity.

The results of the pedagogical experiment showed the level of formation of the linguistic and cultural competence of students, as well as the need for further expansion and improvement of existing knowledge, the formation of communicative skills and abilities that underlie linguistic and cultural competence.

Thus, the necessary prerequisites for the successful formation of linguocultural competence in a foreign language lesson are the observance of certain pedagogical conditions: firstly, the teacher's activity should be aimed at the formation of linguocultural competence; secondly, the process of teaching foreign languages should be communicatively oriented; thirdly, the successful formation of linguistic and cultural competence should be facilitated by interactive teaching methods.

The key role in the formation of linguoculturological competence, in our opinion, is played by studying the proverbs and sayings of a foreign language in the learning process, since cultural characteristics of people of other nation are reflected in proverbs and sayings, as well as the understanding and use of such expressions in speech brings the student's speech to the level of knowledge of their native speakers (SOLNYSHKINA et al., 2018).

Approbation of the proposed methodology was carried out as a part of a pedagogical experiment, in which students were offered a system of special tasks. While working on these tasks, students became acquainted with proverbs and sayings as a special source of linguocultural information, as well as worked out ways to use paremias in oral and written forms of communication. The experiment has proved the efficiency of linguocultural competence formation methodology (TAYUPOVA, 2011). All teaching methods and techniques were oriented towards stimulating students' creative speech and cognitive activity, which increased the effectiveness of teaching a foreign language. It also is characterized by semantic and structural diversity and expresses specific appraisal of the world and a person in it (PLANKINA REGINA et al., 2019). Thereby, the conditions for the successful assimilation of knowledge, the formation and improvement of linguocultural competence were created.

The results of the study devoted to the phased formation of linguocultural competence of students, which has a favorable effect on the learning process of another language and contributes to mastering the necessary competences of another language (DAVLETBAEVA; MEIQI; MINJAR-BELORUCHEVA, 2018). 


\section{Conclusions}

As a result of the study, we confirmed the hypothesis that the formation of linguoculturological competence of students in the middle school will be more successful, if the linguoculturological aspect is included in the content of teaching foreign language, involving the use of linguistic and cultural material as a valuable source of linguoculturological information.

ACKNOWLEDGEMENTS: The work is performed according to the Russian Government Program of Competitive Growth of Kazan Federal University.

\section{REFERENCES}

AYUPOVA, R.; ARSENTEVA, E.; LUTFULLINA, G.; NIKULINA, E. Identifying The Key Components of Phraseological Units. Humanities \& Social Sciences Reviews, v. 8, n. 1, p. 233-239, 2020.

DAVLETBAEVA, D. N.; MEIQI, L.; MINJAR-BELORUCHEVA, A. P. Linguistic Knowledge Of Russian And English Bilinguism In Educational Discourse. Modern Journal of Language Teaching Methods, v. 8, n. 10, p. 419-422, 2018.

GURYANOV, I. O.; RAKHIMOVA, A. E.; RUDNICK, A. Socio-cultural aspect of coloristic components of idioms in german discourse. QUID: Investigación, Ciencia y Tecnología, $\mathrm{n}$. 1, p. 800-805, 2017.

MUKHAMADIAROVA ALBINA, F.; MERKISH NATALIYA, E.; KULKOVA MARIYA, A. The advantages of using multimedia cultural and linguistic environment in the process of teaching foreign languages. Revista Publicando, v. 5, n. 16, p. 332-339, 2018.

PLANKINA REGINA, M.; PESTOVA MARIA, S.; TARASOVA FANUZA, H.; YAKHINA ALBINA, M. Evaluative Component in the Meaning of Verbal Phraseological Units of English, Russian and Tatar Languages. Journal of Research in Applied Linguistics, v. 10, n. 2, p. 762-769, 2019.

SOLNYSHKINA, M.; KAZACHKOVA, M.; GAFIYATOVA, E.; VARLAMOVA, E. Linking words in russian social studies course books: a study on text complexity. In: INTERNATIONAL CONFERENCE ON EDUCATION, SOCIAL SCIENCES AND HUMANITIES, 4., 2018, Dubai. Proceedings [...]. Dubai: SOCIOINT, 2018. p. 764-771.

TAYUPOVA, O. I. Extralinguistic Features of texts nemeckij yazyk v bashkortostane: problemy i perspektivy. In: Materialy 6-j Mezhdunarodnoj nauchno-prakticheskoj konferencii. 2011. p. 194-199. 
TULUSINA, E. A.; SADYKOVA, A. G.; FREDERIC, C. Determination of national specificity of perceiving the concept "learning" in german and russian through the association experiment. Astra Salvensis, v. 10, 2017.

ZHUMASHEVA, A. S.; SAMETOVA, F. T.; MUKTAROVA, E.; BATYRKHAN, B. S.; SULTANIYAZOVA, I. S. About a lingvocultural interference in the conditions of dialogue between cultures. Life Science Journal, v. 11, n. esp. 7, p. 360-364, 2014.

\section{How to reference this article}

TUluSinA, E. A.; SADYKOVA, A. G.; ZARIPOVA, Z. M.; CARLSON, C. F. Linguocultural competence as a basis for foreign language proficiency. Rev. EntreLínguas, Araraquara, v. 7, n. esp. 1, p. 105-125, fev. 2021. e-ISSN: 2447-3529. DOI: https://doi.org/10.29051/el.v7iEsp1.14878

Submitted: $28 / 10 / 2020$

Required revisions: $19 / 12 / 2020$

Approved: 13/01/2021

Published: 28/02/2021 